\title{
Mitochondrial DNA Clocks and the Phylogeny of DANAUS BUTTERfLIES
}

\author{
Gugs Lushai ${ }^{1}$, David A. S. Smith ${ }^{2}$, Dave Goulson ${ }^{1}$, John A. Allen ${ }^{1}$ \\ AND NORMAN MACLEAN ${ }^{1}$ \\ ${ }^{1}$ Ecology and Biodiversity Division, School of Biological Sciences, University of Southampton, \\ Bassett Crescent East, Southampton SO16 7PX, UK; \\ ${ }^{2}$ Natural History Museum, Eton College, Windsor SL4 6EW, UK
}

(Accepted19 September 2003)

\begin{abstract}
Molecular clocks based on sequence change in mitochondrial (mt) DNA have been useful for placing molecular phylogenies in their historical context, thereby enhancing evolutionary insight. Nonetheless, despite their importance to phylogeographers, the methodology is controversial. Here we report on two mitochondrial clocks for the butterfly genus Danaus based on sequences from the cytochrome c oxidase subunit I (COI) and small subunit 12S rRNA (12S) genes. Both clocks are, within the context of Danaus, reliable time-keepers, mutually consistent and, respectively, in agreement with a crustacean COI clock and a molluscan $12 \mathrm{~S}$ clock. Though we have no fossils with which directly to calibrate sequence divergence rates for Danaus, the $12 \mathrm{~S}$ molluscan and COI crustacean clocks chosen for comparison were calibrated to radiometrically dated geomorphological events. Our results indicate that the Danaus COI clock evolves approximately four times faster than the $12 \mathrm{~S}$ clock. Differences between rates of sequence change in terminal sister-taxa are small and likelihood ratio tests do not reject a hypothesis that evolution has been clock-like. The species Danaus chrysippus is paraphyletic and, therefore, invalid. Danaus probably split from its sister-genus Tirumala around $4.9 \pm 0.3$ million years ago in the early Pliocene.
\end{abstract}

Key Words: COI, Danaus, molecular clocks, molecular phylogenetics, mitochondrial DNA, $12 \mathrm{~S}$ rRNA

Résumé-Les horloges moléculaires basées sur le changement de séquence de l'ADN mitochondrial (mt) ont été utiles pour replacer les phylogénies moléculaires dans leur contexte historique, et ainsi améliorer nos connaissances sur l'évolution. Cependant, malgré leur importance pour les phylogéographes, la méthodologie est contestée. Nous présentons ici deux horloges moléculaires pour le papillon du genre Danaus établies sur les séquences des gènes du cytochrome c oxidase sous unité I (COI) et la petite sous unité $12 \mathrm{~S}$ rRNA (12S). Les deux horloges sont, dans le contexte du genre Danaus, des chronomètres fiables, mutuellement compatibles et, respectivement, en accord avec l'horloge de crustacé COI et l'horloge de mollusque 12S. Bien que nous n'ayons pas de fossile avec lequel calibrer les taux de divergence des séquences pour Danaus, les horloges de mollusque $12 \mathrm{~S}$ et de crustacé COI choisis pour comparaison ont été calibrées avec des événements géomorphologiques datés par radiométrie. Nos résultats indiquent que chez Danaus l'horloge COI évolue approximativement 4 fois plus vite que l'horloge 12S. Les différences entre les taux de changement de séquence de taxons frères terminaux sont faibles et les tests du taux de vraisemblance ne rejettent pas l'hypothèse selon laquelle l'évolution a été régulière. L'espèce Danaus chrysippus est paraphylétique et, par conséquent non valide. Le genre Danaus s'est probablement séparé de son genre frère il y a environ $4,9 \pm 0,3$ millions d'années au début du Pliocène.

Mots Clés: COI, horloges moléculaires, phylogénie moléculaire, ADN mitochondrial, ARNr $12 S$ 


\section{INTRODUCTION}

$\mathrm{E}$ ver since Zuckerhandl and Pauling (1965) proposed that protein and DNA sequences might change at constant rates over time, attempts to provide time-frames for molecular studies in phylogenetics and phylogeography have proliferated. Whereas reviewers (Hillis et al., 1996; Li, 1997; Page and Holmes, 1998) counsel caution in the application of molecular clocks, some authors maintain, not only that time is the best single predictor of genetic divergence (Bermingham and Lessios, 1993; Brown, 1983; DeSalle et al., 1987), but also that 'overall evolutionary rates remain relatively constant among diverse taxa' (Wilson et al., 1985; see Avise [1994] for discussion). Moreover, it is widely accepted that, in most cases, DNA base pair mutations accrue in an approximately linear manner over time-scales less than, say, 10 million years (Brower, 1994; Brown et al., 1979; Lessios, 1979; Reid et al., 1996; Wilson et al., 1985). Many animal mitochondrial (mt) DNA clocks, in particular, have proved robust to empirical testing.

The most widely applied calibration for the evolutionary rate of animal mt DNA is $2 \%$ sequence divergence per million years (Ma) (Brown et al., 1979). Indeed, Wilson et al. (1985) conclude that 'the mean rate of divergence averaged over the whole molecule is about $2 \%$ per $\mathrm{Ma}$ in animals as diverse as primates, rhinoceroses, rodents, the genus Equus, artiodactyls, gallinaceous birds, geese, frogs, salmonid fishes and Hawaiian Drosophila'. This confident claim has not survived unscathed (Avise, 1994, 2000; Hillis et al., 1996; Li, 1997; Page and Holmes, 1998; and references therein). Moreover, the raw data were heavily biased to vertebrates. However, the consensus was broadly supported for insects by Brower (1994), who proposed a calibration of $2.3 \% \mathrm{mt}$ DNA sequence divergence per $\mathrm{Ma}$, based on a heterogeneous DNA database extracted from seven recently diverged ( $3.25 \mathrm{Ma})$ arthropod groups. However, this analysis took no account of variation known to occur widely in clock rates across mitochondrial loci.

Here we present mt DNA sequence data, collected primarily for other purposes (Lushai et al., 2003a-b), for Danaus (Lepidoptera: Danainae), a pantropical genus of butterflies comprising 11 species (Ackery and Vane-Wright, 1984). The contrast between highly conserved sequences in the rRNA-coding, small subunit $12 \mathrm{~S}$ gene (12S) and the relative diversity of the polypeptidecoding cytochrome c oxidase I (COI) gene attracted our attention. Invertebrate clocks for these individual genes have been described for example, for 125 by Rumbak et al. (1994) and for COI by Knowlton et al. (1993). Rumbak et al. (1994) reported a sequence divergence rate for $12 S$ of $0.6 \%$ per Ma in the Holarctic marine gastropod genus Littorina. Site change in the protein-coding cytochrome b gene (Reid et al., 1996) was approximately ten times faster than $12 \mathrm{~S}$, though the data for the two genes were not strictly comparable. Knowlton et al. (1993) described a sequence divergence rate of $2.4 \%$ per Ma for COI in a genus of prawns (Alpheus spp.) (Crustacea: Decapoda). The particular value of the Littorina and Alpheus clocks to this study is that both were calibrated by radiometric methods to geological events that probably caused vicariance within their respective genera.

In this paper, we first examine the evidence that the $12 \mathrm{~S}$ and COI genes in the 10 danaine taxa investigated (Table 1) have evolved at the same rate, and that both have evolved individually in a clock-like manner. In the absence of other historical evidence for dating butterfly divergence rates, we then compare our estimates with those for the same genes in Littorina (Rumbak et al., 1994) and Alpheus (Knowlton et al., 1993), respectively. Finally, we propose a historical framework for the evolution of both genes in Danaus and comment on some unusual features of the Danaus phylogeny. A short time-scale $(<10$ Ma) for the radiation of Danaus, that precludes variable site saturation (Avise, 1994), is assumed and justified. The nine taxa of Danaus included are relatively homogeneous for key variables, such as body size, generation time, morphology, physiology, biochemistry, biogeography, ecology and behaviour (Ackery and Vane-Wright, 1984), all of which are known sometimes to influence rates of mt DNA evolution (Avise, 1994, 2000).

\section{Materials And Methods}

DNA for the polymerase chain reaction (PCR) was extracted from samples of nine Danaus lineages comprising five species of Danaus and five lineages ( subspecies) of D. chrysippus. Other danaine species, Tirumala septentrionis, Ideopsis similis and Amauris niavius, served as outgroups (Table 1). All butterflies were collected randomly 
in the field, boxed alive and killed with ethyl ethanoate vapour immediately before storage in ethanol at $-20^{\circ} \mathrm{C}$.

Laboratory methods for extraction, amplification and sequencing of DNA are described in Lushai et al. (2003a). Primers for the first run of COI sequencing were, COI-F, 5' gga gga ttt gga aat tga tta gtt cc $3^{\prime}$ and COI-R 5 ' tcc aat gca cta atc tgc cat att a 3'; for the second run they were: COI-RLR $5^{\prime}$ ttg att ttt tgg tca aga agt $3^{\prime}$ and BIATP6R 5' ata ctt ctc tag cat ata aag $t$ 3'.

The $12 \mathrm{~S}$ tree was rooted by the out group method using I. similis and T. septentrionis and, similarly, the COI tree was rooted using $A$. niavius and T. septentrionis. The PHYLIP 3.573c program (Felsenstein, 1993) was used for maximum likelihood (ML) analysis and PAUP 4.0b (Swofford, 1998) for maximum parsimony (MP), in the latter case, exploring both heuristic and branch and bound models. 1000 Bootstrap-Bremer support values are shown for each MP node (Bremer, 1994). Trees were analysed for measures of branch lengths and various pairwise comparisons (PAUP: uncorrected- $p$ and TamuraNei models) were used to determine genetic distances (Table 2a), from which time estimates (Table 2b) were calculated. Branch significance was tested using PHYLIP: ML. Sequences were submitted to GenBank (Table 1) using the National Center for Biotechnology Information's submission program SEQUIN 3.7. The likelihood ratio statistic was used to test the $12 \mathrm{~S}$ and COI loci for a 'molecular clock' evolutionary rate.

\section{Results AND Discussion}

\section{Comparison of $12 \mathrm{~S}$ and COI clock rates}

Sequence divergence values for the $12 \mathrm{~S}$ and COI mt genes among all Danaus terminal clades (Fig. 1) and T. septentrionis, are shown in Table 2a. The two data-sets are tested for consistency with each other by a Mantel Test, which gives $r=0.83 ; \mathrm{P}=$

Table 1. Provenances and sample sizes for butterflies of the tribe Danaini used to sequence the $12 \mathrm{~S}$ and COI mitochondrial genes. COI sample sizes in parentheses indicate repeat sequences $(540 \mathrm{bp})$ obtained with the alternative primer from the same specimens

\begin{tabular}{|c|c|c|c|c|c|}
\hline \multirow[b]{2}{*}{ Taxon } & \multirow[b]{2}{*}{ Source } & \multicolumn{2}{|c|}{$12 S(347 \mathrm{bp})$} & \multicolumn{2}{|c|}{ COI (676 bp) } \\
\hline & & $N$ & GenBank & $N$ & GenBank \\
\hline Ideopsis similis & Malaysia & 4 & AY256845 & - & - \\
\hline Amauris niavius & Tanzania & - & - & $1(1)$ & AY256343 \\
\hline Tirumala septentrionis & Malaysia & 8 & AF389888 & 8 & AF394182 \\
\hline Danaus plexippus & Australia, USA & 14 & AF389889 & $8(1)$ & AF394183 \\
\hline D. genutia & Thailand, Malaysia & 11 & AF389892 & $2(1)$ & AY256344 \\
\hline D. eresimus & Cayman Is. & 8 & AF389895 & 8 & AF394185 \\
\hline D. gilippus & Cayman Is. & 8 & AF389896 & 8 & AF394186 \\
\hline D. chrysippus dorippus & Kenya & 13 & AF389890 & $6(2)$ & AF394184 \\
\hline D.c.petilia & Australia & 9 & AF389898 & 8 & AF394188 \\
\hline D. c. bataviana & Malaysia & 13 & AF389899 & $8(1)$ & AF394189 \\
\hline D.c.alcippus & Ghana, Uganda & 26 & AF389901 & $9(1)$ & AF394191 \\
\hline D.c. chrysippus & Zambia, Tanzania & 23 & AF389903 & $12(2)$ & AF394193 \\
\hline
\end{tabular}

Table 2a. Uncorrected ' $p$ ' genetic distances for COI (above diagonal) and 12S rRNA (below diagonal) mitochondrial genes for Danaus taxa with Tirumala septentrionis as outgroup

\begin{tabular}{|c|c|c|c|c|c|c|c|c|c|c|c|}
\hline & & 1 & 2 & 3 & 4 & 5 & 6 & 7 & 8 & 9 & 10 \\
\hline 1 & Tirumala & - & 0.104 & 0.100 & 0.098 & 0.109 & 0.109 & 0.109 & 0.111 & 0.109 & 0.109 \\
\hline 2 & plexippus & 0.020 & - & 0.063 & 0.057 & 0.078 & 0.078 & 0.076 & 0.083 & 0.081 & 0.081 \\
\hline 3 & dorippus & 0.026 & 0.012 & - & 0.063 & 0.080 & 0.080 & 0.085 & 0.085 & 0.083 & 0.083 \\
\hline 4 & genutia & 0.029 & 0.015 & 0.015 & - & 0.067 & 0.067 & 0.070 & 0.072 & 0.070 & 0.070 \\
\hline 5 & eresimus & 0.047 & 0.032 & 0.032 & 0.029 & - & 0.000 & 0.067 & 0.063 & 0.065 & 0.065 \\
\hline 6 & gilippus & 0.044 & 0.029 & 0.029 & 0.026 & 0.003 & - & 0.067 & 0.063 & 0.065 & 0.065 \\
\hline 7 & petilia & 0.035 & 0.026 & 0.020 & 0.023 & 0.026 & 0.023 & - & 0.033 & 0.031 & 0.031 \\
\hline 8 & bataviana & 0.029 & 0.020 & 0.015 & 0.017 & 0.020 & 0.017 & 0.006 & - & 0.006 & 0.006 \\
\hline 9 & chrysippus & 0.029 & 0.020 & 0.015 & 0.017 & 0.020 & 0.017 & 0.006 & 0.000 & - & 0.002 \\
\hline 10 & alcippus & 0.029 & 0.020 & 0.015 & 0.017 & 0.020 & 0.017 & 0.006 & 0.006 & 0.006 & - \\
\hline
\end{tabular}


Table 2b. Matrix showing estimated divergence dates (Ma BP) for Danaus taxa and Tirumala septentrionis. Dates are derived from uncorrected ' $p$ ' sequences (Table 2a) with calibrations of $2.4 \%$ divergence per Ma for COI (above diagonal) and $0.6 \%$ per Ma for $12 \mathrm{~S}$ (below diagonal)

\begin{tabular}{|c|c|c|c|c|c|c|c|c|c|c|c|}
\hline & & 1 & 2 & 3 & 4 & 5 & 6 & 7 & 8 & 9 & 10 \\
\hline 1 & Tirumala & - & 4.32 & 4.17 & 4.09 & 4.55 & 4.55 & 4.55 & 4.63 & 4.55 & 4.55 \\
\hline 2 & plexippus & 3.39 & - & 2.62 & 2.39 & 3.24 & 3.24 & 3.16 & 3.47 & 3.40 & 3.40 \\
\hline 3 & dorippus & 4.36 & 1.94 & - & 2.62 & 3.32 & 3.32 & 3.55 & 3.55 & 3.47 & 3.47 \\
\hline 4 & genutia & 4.84 & 2.42 & 2.43 & - & 2.78 & 2.78 & 2.93 & 3.01 & 2.93 & 2.93 \\
\hline 5 & eresimus & 7.75 & 5.33 & 5.33 & 4.83 & - & 0.00 & 2.78 & 2.62 & 2.70 & 2.70 \\
\hline 6 & gilippus & 7.27 & 4.84 & 4.85 & 4.35 & 0.01 & - & 2.78 & 2.62 & 2.70 & 2.70 \\
\hline 7 & petilia & 5.84 & 4.38 & 3.41 & 3.88 & 4.38 & 3.88 & - & 1.39 & 1.31 & 1.31 \\
\hline 8 & bataviana & 4.87 & 3.40 & 2.43 & 2.91 & 3.41 & 2.91 & 0.97 & - & 0.23 & 0.23 \\
\hline 9 & chrysippus & 4.87 & 3.40 & 2.43 & 2.91 & 3.41 & 2.91 & 0.97 & 0.00 & - & 0.08 \\
\hline 10 & alcippus & 4.86 & 3.40 & 2.43 & 2.91 & 3.41 & 2.91 & 0.97 & 1.00 & 1.00 & - \\
\hline
\end{tabular}

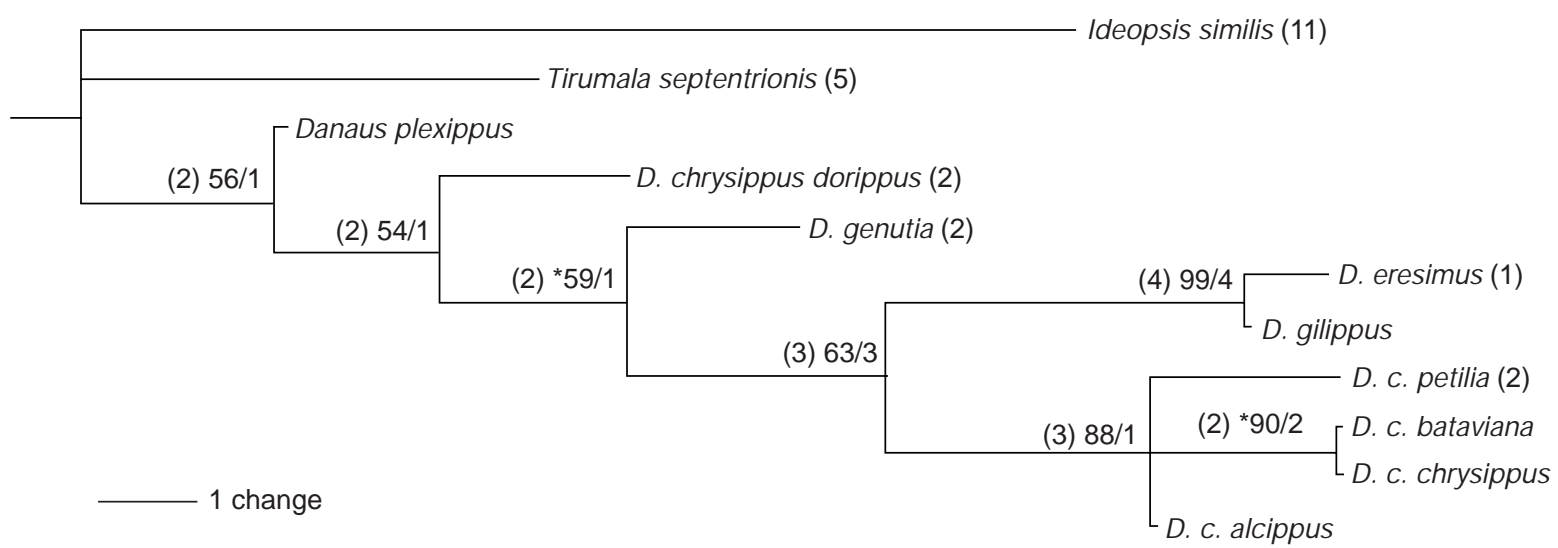

Fig. 1a. Single most parsimonious tree based on the $12 S$ rRNA gene for the genus Danaus rooted by outgroup Ideopsis similis and Tirumala septentrionis. Tree statistics: characters in matrix 348, variable uninformative characters 19 , parsimony informative characters 16 , heuristic search length $=41$, consistency index $=0.87$, homoplasy index $=0.12$, retention index $=0.85$, rescaled consistency index $=0.74 .1000$ Bootstrap replicates / Bremer Support values are shown for each node. Branch lengths are drawn proportional to nucleotide changes and indicated in parentheses. All branch lengths have ML branch significance $(\mathrm{P}<0.01)$ unless marked*. See Table 1 for sample sizes, provenance and an explanation of the names of D. chrysippus taxa

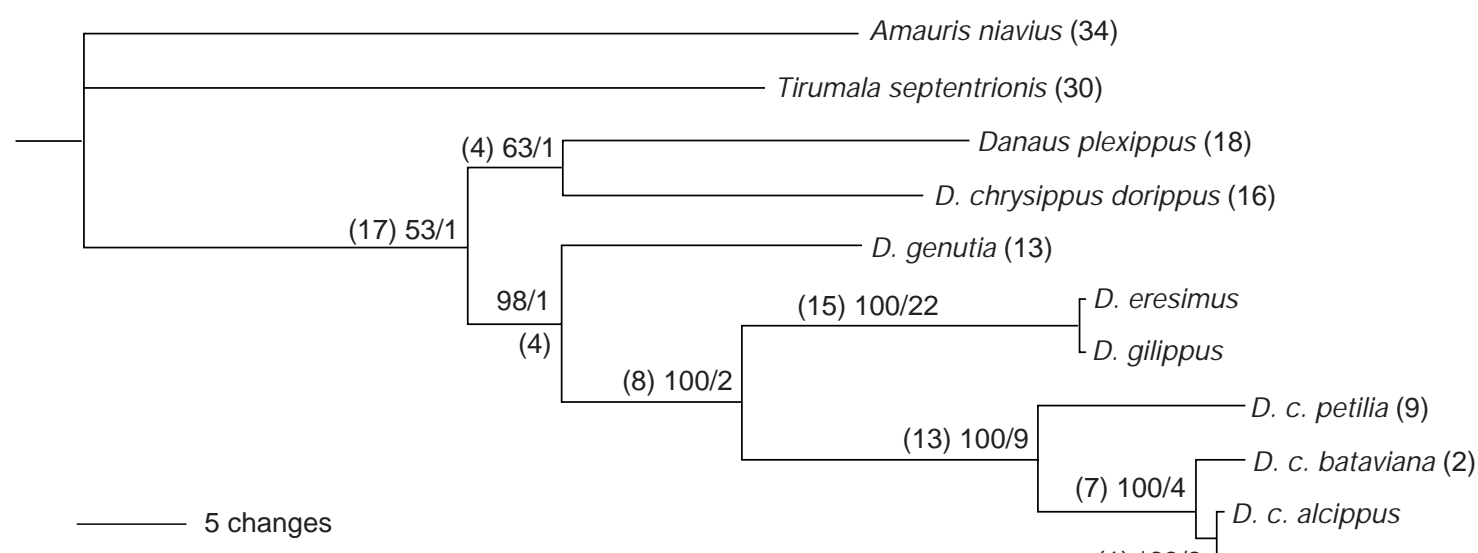

(1) *63/3 D. c. chrysippus

Fig. 1b. One of four most parsimonious trees based on the COI gene for the genus Danaus rooted by outgroup Amauris niavius and Tirumala septentrionis. Tree statistics: characters in matrix 540, variable uninformative characters 53 , parsimony informative characters 74 , heuristic search length $=191$, consistency index $=0.77$, homoplasy index $=$ 0.22 , retention index $=0.69$, rescaled consistency index $=0.53$. Other details are as for Fig. $1 \mathrm{a}$ 
0.005 , a significant result. Mean divergence of the nine Danaus taxa from Tirumala is $3.20 \pm 0.09 \%$ for $12 \mathrm{~S}$ and $10.66 \pm 0.05 \%$ for COI. The empirical ratio for divergence rate for the whole COI:12S dataset is 3.77:1 $\left(\mathrm{CI}_{95}\right.$ 3.44-4.10:1). However, closer examination of the raw data (Table $2 \mathrm{a}$ ) suggests that the substitution rate in the $12 \mathrm{~S}$ gene was higher within the (eresimus + gilippus) clade and was significantly heterogeneous compared to the other clades. Therefore, while acknowledging this caveat, the COI gene evolved at an average rate approximating 3.8 times faster than the $12 \mathrm{~S}$ gene.

Comparing mean site mutation rates of the Danaus taxa since cladogenesis from Tirumala in the $12 \mathrm{~S}(\mathrm{P}=0.030, n=347)$ and $\mathrm{COI}(\mathrm{P}=0.080, n=$ $540)$ sequences, assuming binomial distributions, $z=3.391 ; \mathrm{P}<0.001$ : thus, a null hypothesis that the genes evolve at the same rate is firmly rejected.

The ratio 2.4:0.6 $=4: 1$, derived from the clock rates of $2.4 \%$ per Ma for COI (Knowlton et al., 1993) and 0.6\% per Ma for $12 S$ (Reid et al., 1996; Rumbak et al., 1994), is not significantly different from the empirical mean divergence ratio among Danaus taxa and Tirumala of 3.77:1 $\left(t_{40}=1.4, \mathrm{NS}\right)$. Thus, when tested against a hypothesis that the global ratio for rates of sequence divergence in COI and $12 \mathrm{~S}$ is $\sim 4: 1$, there is statistical agreement between the empirical data and expectation. On the assumption that the agreement is real, and it is statistically improbable to be otherwise, we estimate divergences among the 10 terminal clades as (\% uncorrected $p$ distance $\div \%$ change per $\mathrm{Ma})=$ time $(\mathrm{Ma})$ since cladogenesis (Table $2 \mathrm{~b})$. (NB. Uncorrected- $p$ and Tamura-Nei distances are identical for this data-set).

The most appropriate tool for testing rate variation is the likelihood ratio statistic $\left(\Delta^{2}\right)$ in which maximum log-likelihoods of an ultrametric tree $\left(H_{0}\right)$ and an additive tree $\left(H_{1}\right)$ are compared (likelihood ratio test) (Goldman, 1993). Given a constant rate of evolution an ultrametric tree (clock enforced) would not differ significantly from an additive one (no clock). The test statistic, $2 \Delta=2\left(\log L_{\text {no clock }}-\log L_{\text {clock }}\right)$, is approximately distributed as a $\chi^{2}$ with $(N-2)$ degrees of freedom, where $N$ is the number of taxa. For the $12 \mathrm{~S}$ tree, $\chi^{2}{ }_{9}=14.23,0.10>\mathrm{P}>0.05$; for COI, $\chi^{2}{ }_{9}=3.90,0.95$ $>\mathrm{P}>0.90$. Although neither test rejects $H_{0}$, the $12 \mathrm{~S}$ result approaches statistical significance at the $5 \%$ level, which is explained by the higher substitution rate in the (eresimus + gilippus) clade (Table 2a). Since the Neotropical sister-species pair eresimus and gilippus is, on the evidence of both genes, recently diverged, the faster than average $12 \mathrm{~S}$ substitution rate has occurred in the common ancestor.

\section{Some aspects of the Danaus phylogeny}

The topologies of both $12 \mathrm{~S}$ and COI phylogenetic trees (Fig. 1) derived from MP (heuristic and branch and bound models) and ML algorithms are concordant. A surprising feature of both trees is that four subspecies of D. chrysippus constitute, as expected, a monophyletic group, but one that is paraphyletic to the fifth subspecies dorippus. In the $12 \mathrm{~S}$ phylogeny (Fig. 1a), descendents of the nearest common ancestor of D. c. dorippus, on the one hand, and the other four chrysippus subspecies, on the other, include no less than three additional species-genutia, eresimus and gilippus. The COI phylogeny (Fig. 1b) is in most respects concordant with the $12 \mathrm{~S}$ tree but, in this case, the five chrysippus subspecies share their nearest common ancestor with all the Danaus species included in the study. Furthermore, we have preliminary sequences for the EF1 nuclear gene in Danaus and the outgroup Amauris that support the mitochondrial data, in particular in showing D. c. chrysippus as paraphyletic to $D$. c. dorippus (results not shown).

According to independent analyses, then, $D$. chrysippus is not a phylogenetic species as defined by Cracraft (1983). And yet, this finding is paradoxical because its subspecies dorippus, chrysippus and alcippus hybridise extensively in East Africa (Smith et al., 1998; Lushai et al., 2003a, b) to produce offspring fertile in both sexes: thus, D. chrysippus has generally been regarded as a biological species (Mayr, 1942) that is both polymorphic and polytypic (Smith et al., 1997). Because the dorippus result, in particular, challenges taxonomic orthodoxy, the COI genes of dorippus and other representative taxa were sequenced twice using different primers (Table 1); in every case the original sequences were confirmed.

The case of the Neotropical sister-species pair eresimus and gilippus is equally intriguing. From distribution data given by Ackery and VaneWright (1984), we estimate that the former species, including the probably conspecific D. plexaure (G. Lamas in Ackery and Vane-Wright, 1984), is 95\% sympatric with the latter over a vast area of the New World tropics and subtropics from Texas and Florida in the north to Argentina in the south. 
Based on the two mitochondrial sequences (1023 bp), the two species sampled on Grand Cayman have a genetic distance of only $0.1 \%$. And yet, although almost nothing is known of their comparative ecology, they are morphologically distinct (Ackery and Vane-Wright, 1984), reproductively isolated and exhibit reproductive character displacement (Smith et al., 2002). They may have speciated in sympatry or parapatry within the last 40,000 years at most. Alternatively, it is possible that hybridisation between the species at some stage in their history has caused cytoplasmic introgression between them; if this is the case their nuclear DNA may be well differentiated. We hope to resolve this question in a future study by investigating both mitochondrial and nuclear genes from both species in other parts of their very extensive shared range.

\section{Chronology of the Danaus phylogeny}

Butterflies are rarely fossilised and there is no dated palaeontological, palaeoclimatological or geological evidence against which directly to calibrate molecular clocks for Danaus. Therefore, to place the Danaus phylogeny (Fig. 1) in a historical setting we adopt local clocks (Knowlton et al., 1993; Rumbak et al., 1994) that were originally calibrated to geological events dated by radioactive decay curves. The selected $12 S$ and COI clocks were originally used to date phylogenies for closely related and recently evolved groups of invertebrates, with low absolute amounts of sequence variation. The $12 \mathrm{~S}$ clock is calibrated by two dated vicariance events, starting with the opening of the Bering Strait ( 3.5-4.0 Ma BP, Hopkins, 1967) and ending at the onset of widespread glaciation $(\sim 2.4 \mathrm{Ma} B \mathrm{BP}$, Shackleton et al., 1984). The clock was applied to a phylogeny for Littorina, a Holarctic genus of marine gastropod molluscs, (Reid et al., 1996; Rumbak et al., 1994). For a COI calibration we adopt a clock for prawns of the genus Alpheus (Crustacea: Decapoda) from Panama (Knowlton et al., 1993). In the latter case, the final completion of the Panama Isthmus, postulated as the cause of vicariance in four geminate species-pairs of Alpheus, is dated at 3.0-3.5 Ma BP (Lessios, 1998).

A comparison of average rates of sequence divergence from Tirumala for the protein-coding COI gene and the rRNA-coding $12 S$ gene (Table 2a) suggests that, within Danaus, the former has evolved some four times faster than the latter ( $P$
$<0.001)$. Albeit the divergence rates for each terminal clade are only partially independent, the COI:12S ratio varies across the nine Danaus taxa within the range 2.3:1-5.8:1, with a mean of 3.8:1. Thus, on the evidence of partial sequences, a null hypothesis that the two mitochondrial genes evolve at the same rate is firmly and consistently rejected for Danaus. Furthermore, the empirical ratio of 3.8:1 for COI:12S sequence evolution rates in Danaus is not significantly different from an expected ratio of $4: 1$ calculated from the clock values of $2.4 \%$ per Ma for COI (Knowlton et al., 1993) and 0.6\% per Ma for $12 S$ (Reid et al., 1996; Rumbak et al., 1994). Therefore, although our observations fall short of demonstrating global invertebrate clocks for the COI and $12 \mathrm{~S}$ loci, the close and statistically significant agreement between the two Danaus clocks and their counterparts in molluscs and crustaceans, suggests they may have global predictive power when applied to closely related and recently evolved animal phylogenies. Generally near-zero differences between divergence rates of terminal clades suggest that a null hypothesis of uniform rates of sequence evolution in Danaus is not rejected.

The mean of the Tirumala-Danaus genetic distances converted to their time equivalents $(N$ $=18$, Table $2 \mathrm{~b}$ ) suggests that Danaus split from Tirumala around $4.9 \pm 0.06$ million years ago in the early Pliocene.

Acknowledgements-We acknowledge financial support from The Leverhulme Trust, grant F / 180 / AP. For hospitality while on field work, we thank Ian Gordon, Lorna Depew, Henry and Eliza Harford, Christopher and Elizabeth Wood. We are deeply indebted to those who collected material for us: Fred Ansah, Andrew Brower, Ian Gordon, Francis Jiggins and Myron Zalucki. The observations of an anonymous referee have improved the paper.

\section{REFERENCES}

Ackery P. R. and Vane-Wright R. I. (1984) Milkweed Butterflies. British Museum (Natural History), London. 425 pp.

Avise J. C. (1994) Molecular Markers, Natural History and Evolution. Chapman and Hall, New York. 511 pp.

Avise J. C. (2000) Phylogeography: The History and Formation of Species. Harvard University Press, Cambridge. 447 pp.

Bermingham E. and Lessios H. (1993) Rate variation of protein and mtDNA evolution as revealed by sea 
urchins separated by the Isthmus of Panama. Proc. Natl. Acad. Sci. USA 90, 2734-2738.

Bremer K. (1994) Branch support and tree stability. Cladistics 10, 295-304.

Brower A. Z. (1994) Rapid morphological radiation and convergence among races of Heliconius erato inferred from patterns of mitochondrial DNA evolution. Proc. Natl. Acad. Sci. USA 91, 6491-6495.

Brown W. M. (1983) Evolution of animal mitochondrial DNA, pp. 62-88. In Evolution of Genes and Proteins (Edited by M. Nei and R. K. Koehn). Sinauer, Sunderland.

Brown W. M., George M. Jr and Wilson A. C. (1979) Rapid evolution of animal mitochondrial DNA. Proc. Natl. Acad. Sci. USA 76, 1967-1971.

Cracraft J. (1983) Species concepts and speciation analysis. Current Ornithology 1, 159-187.

DeSalle R., Freedman T., Prager E. M. and Wilson A. C. (1987) Tempo and mode of sequence evolution in mitochondrial DNA of Hawaiian Drosophila. J. Mol. Evol. 26, 157-164.

Felsenstein J. (1993) PHYLIP (phylogeny inference package) version 3.5. Distributed by the author, Department of Genetics, University of Washington, Seattle.

Goldman N. (1993) Statistical tests of models of DNA substitution. J. Mol. Evol. 36, 182-198.

Hillis D. M., Mable B. K. and Moritz C. (1996) Applications of molecular systematics: The state of the field and a look to the future, pp. 515-543. In Molecular Systematics (2nd edn) (Edited by D. M. Hillis, C. Moritz and B. K. Mable). Sinauer, Sunderland.

Hopkins D. M. (1967) The Cenozoic history of Beringia: A synthesis, pp. 451-484. In The Bering Land Bridge (Edited by D. M. Hopkins). Stanford University Press, Stanford.

Knowlton N., Weight L. A., Solorzano L. A., Mills D. K. and Bermingham E. (1993) Divergence in proteins, mitochondrial DNA and reproductive compatibility across the Isthmus of Panama. Science 260, 1629-1632.

Lessios H. A. (1979) Use of Panamian sea urchins to test the molecular clock. Nature 280, 599-601.

Lessios H. A. (1998) The first stage of speciation as seen in organisms separated by the isthmus of Panama, pp. 186-201. In Endless Forms: Species and Speciation (Edited by D. J. Howard and S. H. Berlocher). Oxford University Press, New York.

Li W.-H. (1997) Molecular Evolution. Sinauer, Sunderland. 487 pp.

Lushai G., Smith D. A. S., Gordon I. J., Goulson D., Allen J. A. and Maclean N. (2003a) Incomplete sexual isolation between subspecies of the butterfly Danaus chrysippus (L.) and the creation of a hybrid zone. Heredity 90, 236-246.
Lushai G., Zalucki M. P., Goulson D. and Smith D. A. S. (2003b) The lesser wanderer butterfly, formerly known as subspecies petilia (Stoll 1790) of Danaus chrysippus (L.) (1758) (Lepidoptera: Danainae), is a species. Austral. J. Entomol. (in press).

Mayr E. (1942) Systematics and the Origin of Species. Columbia University Press, New York. 450 pp.

Page R. D. M. and Holmes E. G. (1998) Molecular Evolution. Blackwell, Oxford. 346 pp.

Reid D. G., Rumbak E. and Thomas R. H. (1996) DNA, morphology and fossils: Phylogeny and evolutionary rates of the gastropod genus Littorina. Phil. Trans. R. Soc. Lond. B 351, 877-895.

Rumbak E., Reid D. G. and Thomas R. H. (1994) Reconstruction of phylogeny of 11 species of Littorina (Gastropoda: Littorinidae) using mitochondrial sequence data. Nautilus 2, 91-97.

Shackleton N. J., Backman J., Zimmerman H., Kent D. V., Hall M. A., Roberts D. G., Schnitker D., Baldauf J. G., Despraires A., Homrighausen R., Huddlestun P., Keene J. B., Kaltenback A. J., Krumsiek K. A. O., Morton A. C., Murray J. W. and Westberg-Smith J. (1984) Oxygen isotope calibration of the onset of ice-rafting and history of glaciation in the North Atlantic region. Nature 307, 620-623.

Smith D. A. S., Gordon I. J., Depew L. A. and Owen D. F. (1998) Genetics of the butterfly Danaus chrysippus (L.) in a broad hybrid zone, with special reference to sex ratio, polymorphism and intragenomic conflict. Biol. J. Linn. Soc. 65, 1-40.

Smith D. A. S., Gordon I. J., Lushai G., Goulson D., Allen J. A. and Maclean N. (2002) Hybrid queen butterflies from the cross Danaus chrysippus (L.) $x$ D. gilippus (Cramer): Confirmation of species status for the parents and further support for Haldane's Rule. Biol. J. Linn. Soc. 76, 535-544.

Smith D. A. S., Owen D. F., Gordon I. J. and Lowis N. K. (1997) The butterfly Danaus chrysippus (L.) in East Africa: Polymorphism, and morph-ratio clines within a complex, extensive and dynamic hybrid zone. Zool. J. Linn. Soc. 120, 51-78.

Swofford D. L. (1998) PAUP*, Phylogenetic analysis using parsimony (*and other methods), version 4. Sinauer, Sunderland.

Wilson A. C., Cann R. L., Carr S. M., George M. Jr., Gyllensten U. B., Helm-Bychowski K. M., Higuchi R. G., Palumbi S. R., Prager E. M., Sage R. D. and Stoneking M. (1985) Mitochondrial DNA and two perspectives on evolutionary genetics. Biol. J. Linn. Soc. 26, 375-400.

Zuckerhandl E. and Pauling L. (1965) Evolutionary divergence and convergence in proteins, pp. 97166. In Evolving Genes and Proteins (Edited by V. Bryson and H. L. Vogel). Academic Press, New York. 